\title{
Management of ideological and political education under the law school background
}

\author{
Hongbo $\mathrm{Xiu}^{1, \text { a }}$ \\ ${ }^{1}$ College of Automobile \& Civil Engineering, Beihua University, Jilin 132013, China. \\ ahongbo_xiu@126.com
}

Keywords: law school, ideological and political education, innovation management.

\begin{abstract}
China's reform of higher education and improve, the ideological and political education management in universities reveals many deficiencies gradually and affect law school to work vigorously to promote. the rule of law and comprehensively promote the new situation of reform to enhance educational institutions has become an important and urgent task. In this paper, the Marxist theory, law school from the perspective of management of ideological and political education aimed at innovation management is researched in order to promote the legalization of management to improve the ideological and political education management Effectiveness.
\end{abstract}

\section{Introduction}

Conscientiously implement the party's 18 spirit and the scientific concept of development, further promote the "Long-term Education Reform and Development Plan (2010-2020)," the implementation of the full implementation of the requirements of the rule of law, and vigorously promote the law school, the Education Management into the legal track, the deepening of education reform, promote the development of an important part of higher education. Ideological and Political Education Management as an integral aspect of university management has always been an important object of study in higher education. Law school as the basic requirements of the new situation under the current state of higher education proposed research on this subject, it is necessary to start from a theoretical analysis of the connotation of its theoretical basis, combined with ideological and political education of its management practices and ideological and political work Education management relationship between scientific analysis and summary.

Law school is a theoretical concept, from the perspective of the rule of law, the law school is embodied in a legal relationship, mainly by the subject, content and object three elements. Subject Law school is a legal relationship between the rights and obligations of the parties [,], From the macro level refers to the government and educational administration at all levels, from the micro-level point of view refers to the body of the participating colleges and universities, including the Universities leaders, administrators, and faculty and students. Legal content mainly refers to by law to identify and regulate the rights and obligations of the parties, the law school in the mainly refers to the rights and obligations Universities macro level enjoyed by internal University Teachers and students at the micro level of rights and obligations. Legal object refers to the object pointed to legal acts, in the process according to the law school, the law has been summarized in the following objects: schools and other administrative departments; and schools and government administrative department of education; and school principals, teachers, students and their guardians; schools and social organizations, enterprises and citizens; principals, teachers and students and their guardians.

Based on the above analysis, we can make a concept defined in law school: the macro level, the law school means that all levels of government and education authorities and other administrative authorities in order to regulate the behavior of running colleges and universities, according to the legal responsibilities and legal procedures College governance activities carried out; the micro level, refers to the management of the participating colleges and universities actors under the party's leadership, the school for internal affairs in accordance with laws and regulations and the rules and regulations of the school. Core law school is the "rule of law", the "rule of law" nor that "rule of law", one word to express their meaning but far from. "System" means the system, and "governance" refers to governance, both in meaning and expression are different. However, with the continuous 
improvement of the socialist democracy and rigorous thought of "rule of law" has also undergone a transformation on the meaning, specifically in the "rule of law" is the principle of the rule of the ruling layer of democracy as a fundamental national administrative things related processing regulations and standardization, while the implementation of the law, regulatory law provides strict guarantees. "Rule of law" in this sense is closely linked with democracy, the rule of law is a prerequisite for democracy, its purpose and the "rule of law" is the same, are the country according to management. "Rule of law is a long history of ideology, statecraft and social and cultural phenomenon in a different era, people give it different social meaning and significance of the ancient Greek philosopher Aristotle said:.." The rule of law should include the double meaning: the law has been established universal obedience, and we obey the law and should itself be making a very good law.

\section{Principles of Ideological and Political Education in Colleges and Universities under the management reform law school background}

Legal principle is one of the priority elements of administration according to law, by legal restrictions intended to abuse of administrative power to protect the basic rights of citizens. At the same time the law is the principle of priority level represents the essence of the legal effect, but also the country's legal system the fundamental requirement of unity. Law priority principle has broad and narrow sense, broad legal priority principle means the administrative body in the implementation or application of the law when prevail higher law, if the by-laws with the host wears conflict, lower level law invalid, priority higher law; narrow the law refers to the principle of priority in the implementation of the administrative body, applicable laws, regulations, rules, when priority applicable law.

According to the principle of priority laws, ideological and political education based on the development and management of regulatory documents must be China's current constitution, and Higher Education Act made consistent, can not exist in its conflict with the host wears the case, otherwise invalid. Ideological and political education management reform follows the legal requirements of the principle of the priority nature of both the law school, but also reflects the reality of the rule of law. At the same ideological and political education management follows the principle of legal priority to help build a comprehensive management system, its contents and form complete unity to achieve ideological and political education in the management of Legalization.

Since the rule of law arise since thought, Legal Reservation is a subject of concern. The first principle of legal reservation is the parent of German administrative law • Otto Meyer, his definition of reservations given law is: the law refers to retention own role within a specific range of administrative exclusion. Chuan legal and administrative actions, not inconsistent with the requirements of priority to different legal, administrative law reservation made more explicit conduct stringent regulations, it requires agencies to obtain legal authorization only in the case in order to implement the appropriate behavior. "People's Republic of China Legislation Law" Article 8 states that "deprivation of civil and political rights, restriction of personal freedom mandatory measures and penalties" can only be established by law. Ideological and Political Education Management should conscientiously implement the principle of legal reservation, on issues related to fundamental rights and the fundamental interests of the university teachers and students, can only be made in the form of provisions of law, regulations can not be school or department acts as the basis for normative documents.

\section{Law school reform path background Ideological and Political Education Management}

The idea is that people of something beliefs, opinions and beliefs, people are rational knowledge of objective things. Management concept as a specific ideology, reflects a phenomenon inherent to all types of management, recognizing the inevitable contact, the nature of it along with the further development of management practices and continue to develop updated. In the actual ideological and 
political education management in order to improve the ideological and moral education objects, fully mobilize the enthusiasm and awareness education objects, you need to correctly handle the relationship between ideological and political education of the elements, the reasonable solution to the contradiction of ideological and political education inside relationship. Serve as a guide and decisive role in the process of ideological and political education management philosophy, management philosophy is concentrated to a value orientation, this orientation is to optimize the value of ideological and political education.

Comrade Hu Jintao pointed out: "the ideological and political work in the final analysis is a man's work, we must adhere to the people-oriented." [L] adhere to the people-oriented, that is, in the ideological and political education in "We must adhere to educate, guide and inspire people, to spur people, but also to respect, understanding, caring for people, to help people. " Therefore, the ideological and political education management of University as a special order to cultivate high-quality personnel management as the ultimate goal of the management to establish a people-oriented management philosophy. In various management activities, the emphasis on human subjectivity, administrators and managers establish concept. "People-oriented" management philosophy emphasizes individual rights, freedom and equality philosophy, which emphasizes the rule of law and freedom, democracy, equality, the idea is essentially the same. Meanwhile, the ideological and political education "in order to convince people theory" feature, also requires managers to uphold the people-oriented management philosophy in the management process, we performed more humane management, strengthen respect for managers and service awareness, stick management of the main body of the guidance and management of objects. Therefore, to establish people-oriented management philosophy is not only proof of University Law Political Education management requirements, but also the ideological and political education of the decision itself.

\section{Play the whole community together to optimize the management of environmental law}

Ideological and political education environment is the sum of all the objective factors have an impact on the ideological and political education and ideological and political education in colleges and universities affected by the object. From a macro perspective, the environment can be divided into natural and social environment. Subdivided down the social environment can be divided into macro environment and micro environment. Macroeconomic environment, including social and political systems, economic systems, social and cultural systems and their manifestations in real life; microenvironment including family environment, school environment, work environment, network environment, peer group environment. Along with the practice of ideological and political education of human activities is bound to be influenced by the social environment, political environment, economic environment and cultural environment influence ideological and political education are important factors. Create a favorable legal environment, so that students learn in their daily life, the practice of subtle, and gradually develop legal awareness, enhance their legal awareness, encourage law-abiding habits, improve law to protect their rights to participate in the capacity of national and social affairs, both the implementation of quality education, to improve the quality of personnel training an important part, but will also improve the overall quality of national law, promote the rule of law and building a socialist country ruled by law, have a profound impact.

The economic base determines the superstructure, people thought the level and extent of social-economic development and moral qualities are closely related. Productivity is a prerequisite for the development of all, there is no productive development without the development of material civilization and spiritual civilization of socialism, we must adhere to the "science and technology are primary productive forces" principle, vigorously develop the productive forces. In addition, we want to implement priority to efficiency, taking into account the principle of fairness, and constantly improve the social distribution system, establish and improve the economics of legal norms, to establish a harmonious relationship in the interests of society as a whole, leading the market economy into the legal track. At present, China is building a moderately prosperous society in a critical period of economic development has made some achievements, but the face of the development of any 
naturally occurring problem, we must enhance the sense of initiative to adapt to changes in the international and domestic political and economic environment, effective resolving conflicts, more energetic and promising to promote China's reform and opening up and socialist modernization construction, and comprehensively promote the market economy, the rule of law and create a favorable legal environment for the Ideological and political Education of College management by Law.

\section{Summary}

Based on an overview of the law school and the ideological and political education management theory, analysis of the current realities of innovative proofreading Law significance of ideological and political education management, and reveals the ideological and political education management and governance by law contrary to some practical questions and discusses the background of the reform in the law school of University ideological and political education management should adhere to three principles: the legal principle of giving priority to retain legal principles and due process principles. While at law school background, try to put forward several paths ideological and political education management reform. Since this issue is a growing and constantly explore new areas for reference and reference data is relatively small, in addition to their limited capacity, therefore, this issue there are several issues that need further study and discussion.

First, with the reform of the political system and the education system, ideological and political education in colleges and universities manage the problems will continue to highlight the extent of binding law school will gradually deepen. Therefore, how to improve the rule of law in different periods of the current situation of ideological and political education and management, it is a worthwhile long-term research and exploration.

Second, with the development of modern information technology, the network environment Legalization ideological and political education management in colleges and universities has become an important issue can not be ignored, while the ideological and political education management how to correct and effective use of the network environment, how to adapt to the rapid network development has become a problem worthy of study and discussion.

Finally, due to the current development trend of diversified types of colleges and universities, there are comprehensive universities, technical colleges and universities, as well as professional colleges and universities, ideological and political management of different types of colleges and universities have different conditions, the types of colleges and universities in the article did not make a distinction, but the macro Campus Ideological management of research, there are bold aesthetic too, to be in the future for further empirical analysis.

\section{References}

[1] Li Fangyu New Reflection on the Management of Universities Students' Perspective transaction management. Education, 2015 (03).

[2] Tiancheng Chun, Xie Zhi. To develop a charter of the University as an opportunity to comprehensively promote the law school of Sichuan Normal University (Social Science Edition), 2015 (01).

[3] Hu Jiansen. Of the law school's understanding and awareness. Education and Professional, 2015 (01).

Chen Xu. And carry out law school. Education and Professional, 2015 (01).

[4] Wushu Chun. Political Higher Education Management Problems and Solutions. EDUCATION ARTICLE (on Xunkan), 2014 (07). 